\title{
The Board of Directors in timeshare governance: Owner-management relations in timeshare resort operations
}

Received (in revised form): 9 June 2006

\begin{abstract}
Arjun Singh
is the Professor of International Lodging, Finance and Real Estate Finance in The School of Hospitality Business. His MS degree was from Purdue University in Hotel Restaurant and Institutional Management and PhD in Park, Recreation and Tourism from Michigan State University. He is an active member of HAMA (Hospitality Asset Managers Association), CHRIE (Council of Hotel, Restaurant and Institutional Education) and AHFME (Association of Hospitality Financial Management Educators). He was recently invited to join the International Society of Hospitality Consultants, an industry advisory group, consisting of hospitality investment and operations advisors. Dr Singh has over 15 years of hospitality business experience in various management positions in the USA and India. He has worked for Oberoi Hotels, Stouffer Hotels and Hyatt Hotels. In 1999, he taught financial management at Centre International de Glion, a prestigious hotel management school in Switzerland. He has also conducted many Real Estate Market and Feasibility Studies while working as a consultant for Laventhol \& Horwath.
\end{abstract}

\section{Ronald Horwitz}

is Professor Emeritus of Finance at Oakland University (Rochester, MI). He served as Dean of Oakland's School of Business Administration from 1979 to 1990. He is President of the Board of Directors of Marriott Vacation Club International's Desert Springs Villas (Palm Desert, CA) Master Association and serves on the Villas II board. He has lectured extensively on timeshares and timeshare governance in hospitality administration programs of several major universities. He earned his PhD in Financial Administration from Michigan State University and is a CPA. He is very active in hospital governance, serving on the Audit Committee of Ascension Health (St Louis), the finance committee of St. John Health System (Warren, MI) and is secretary of the board of trustees of Providence Hospital and Medical Centers (Southfield, MI).

Ronald Horwitz

School of Business Administration Oakland University

Rochester, MI 48309, USA

E-mail: Horwitz@oakland.edu

Tel: 248-788-9040

Fax: 248-788-9040

\begin{abstract}
The homeowners association plays an important part in the effective operation of a timeshare resort. However, the academic literature lacks a discussion of the role and responsibilities of the association as exercised through an elected Board of Directors. The article discusses the responsibilities of the Board in fostering effective owner-manager relations and its role in successful timeshare resort operations.
\end{abstract}

\section{Keywords:}

timeshare, vacation ownership, Board of Directors, capital expenditure, resort management, governance

Journal of Retail and Leisure Property (2006) 5, 185-196.

doi:10.1057/palgrave.rlp.5100022 


\section{INTRODUCTION}

The term 'timeshare' or 'interval ownership' typically refers to shared ownership in a resort development where a buyer (owner) purchases the right to use accommodations for a specific time period (usually one week) each year. ${ }^{1}$ The history of this concept can be traced back to the 1960 s at a French ski resort. Timeshares 'migrated' to the United States in the late 1960s, and were an adaptation of the original French model, and marketed as the sale of a prepaid vacation. While the original timeshare developments in the United States were primarily conversions of existing condominiums and hotels, the majority of timeshare developments today are 'purpose-built' independent or multiple use resort projects. Timeshares represent the fastest growing segment of the resort development industry in the USA, with 1,668 resorts in 47 states, and 2004 industry sales of approximately $\$ 8$ b. Current industry statistics published by the American Resort Development Association (ARDA) indicate that there are $3.9 \mathrm{~m}$ timeshare owners in the USA, with a total of $5.8 \mathrm{~m}$ timeshare units owned. ${ }^{2}$

The industry overcame its initial image problem with consumers and gained growth momentum primarily due to two events. The concept of exchanging timeshare units owned for other locations made ownership in units appealing as unit owners were not forced to vacation in the same location each year. The exchange service was started by two global exchange companies, Resort Condominium International (RCI) and Interval International in the 1970s. The exchange process impacted the management of timeshare properties, as they were introduced to a new type of property user, an 'exchanger.' The second event that propelled the industry forward was the entrance of major lodging industry companies, led by Marriott in 1984, into this segment of resort development. Subsequently, other lodging companies such as Disney, Hilton, Hyatt followed. ${ }^{3}$ Their association with the branded lodging industry gave timeshare properties higher visibility, credibility and consistent product and service quality.

However, the transition of the timeshare industry led to the juxtaposition of timeshare owners and third-party management companies. From the perspective of the owners and the association that represents them, it meant additional communication with the management company and an understanding of brand standards and elements of guest service and property operations. From the perspective of management companies (primarily experienced in managing traditional hotels and resorts), timeshare property owners were different from owners of typical hotel projects in many ways. In a typical 100 unit timeshare resort that is sold out, management could theoretically have 5,100 owners if each owner purchased one week in the project $(100 \times 51$ weeks $) .{ }^{4}$ Additionally, management companies may interact with owners from other timeshare properties exchanging into their location or redeeming points. Therefore, it was not surprising that a research study on timeshare issues, ranked 'owner relations' in the top five issues, based on 27 issues identified by timeshare executives. 5 


\section{STUDY PURPOSE AND IMPORTANCE}

Timeshare management literature is lacking any discussion of the role of the resort manager in the resort's governance. Further, while their academic training covers the development, sales and operational aspects of property management, the role of timeshare governance is not something with which managers are familiar. This is primarily because many hotel managers move into timeshare resort jobs only with hotel experience and have never dealt with Board of Directors, who represent the interests of timeshare owners. The purpose of this article is to describe the structure, purpose, functions and responsibilities of the Board of Directors in a typical US timeshare resort. ${ }^{6}$ The relationship between the general manager and the resort's Board of Directors is critical to the success of the resort. The authors will examine the role of timeshare governance, discuss the resort manager's role with governance and look at recommendations as to how recent developments in the corporate sector should carryover into timesharing.

\section{THE STATUTORY NATURE OF GOVERNANCE}

Upon purchase of a timeshare interest, the owner automatically becomes a member of the timeshare/condominium/homeowners association. Just as with a corporation, state statutes require a Board of Directors to be responsible for the governance of each association. Timeshare governance refers to the creation and continuance of the Board of Directors, or other governing mechanism, to oversee the affairs of the association.

Timeshare governance is typically determined by documents ${ }^{7}$ variously called:

- Master Deed

- By-laws

- Declaration of Condominium Documents

- Articles of Incorporation.

Most of the important language pertaining to governance is found in the by-laws. The by-laws will usually speak of:

- The number, qualifications and term of office of the directors.

- How they are nominated.

- How to handle board vacancies or resignations.

- Locations and methodologies of board meetings.

- Quorum requirements.

- Committees.

- Powers and duties.

- Election of officers.

Governance structures and practices can vary between properties, even if the same developer is used. Therefore, if a manager moves to another resort managed by the same company, there is no guarantee that governance practices will be the same. Further, the state laws governing the documents can also change from time to time, so the manager should 
encourage the board to have a periodic review by an attorney knowledgeable of the laws of the state in which the resort is located.

\section{MEMBERSHIP AND ELECTIONS}

Most states require a Board of Directors to be established as soon as development has begun. Since it is unlikely that there will be any deeded owners at this time, it is typical for the developer to elect or appoint its own employees to the initial board.

Over time, and in accordance with the by-laws and state requirements, seats on the board will be turned over to owners. Most states require owners to occupy a certain proportion of board seats after a given per cent of the owner-weeks has been sold. Upon sell-out, normally the entire board is turned over to owners, although it is not unusual to find by-laws permitting the developer to retain at least one seat on the board.

Until sell-out, the developer, as a practical matter, is probably in control of a majority of the votes. This is because developers are usually permitted to vote on unsold unit weeks. These developer votes can be critical since in most timeshare developments only about 25-30 per cent of the owners vote in the elections for the Board of Directors. It is not unusual for an election to be void due to the lack of a quorum voting.

The easiest way to avoid a quorum problem in the voting is to provide for proxies. When the notice of the annual meeting and director election is sent out, a proxy form should be included. Usually, the default proxy is given to the board president, unless he/she is a candidate, in which case the senior incumbent is named. However, the problem of owner apathy is still present. Even with the use of proxies, elections have to be postponed. Many boards have solved this dilemma by reducing the quorum requirement for voting to $10-15$ per cent.

There still remains the paucity of information about a candidate. Most timeshare association ballots include, at best, a paragraph about each candidate. It is very unusual to see a campaign mounted, especially in larger resorts. And, despite a nominating committee's best intentions, it is possible for a candidate to have a private agenda that does not become apparent until their first board meeting.

Elections are also complicated by whether the state permits or requires cumulative voting for the directors. Under ordinary voting, an owner is entitled to cast one vote per director seat for each week owned. Under cumulative voting, the owner multiplies the number of directors' seats up for election by the number of weeks owned. This amount can then be voted for as many director candidates as the owner chooses, including placing all of the votes on just one candidate. For example, assume an individual who owned two weeks at a resort with three directors to be elected, would have a total of two votes to place on each of three candidates (ordinary voting rules) but six ( 2 weeks $\times 3$ seats) votes to place, including all six on just one candidate (cumulative voting rules).

Pre-sell-out governance frequently necessitates two boards for a development: one for the condominium association and one for the timeshare association. The 'condo board' is responsible for spaces outside the units including the common elements while the timeshare board 
oversees the governance inside the units. Upon sell-out, the condo board is usually collapsed and all functions are transferred to the timeshare board.

Where the need for both boards is present, it is strategically and economically efficient to have a common membership. To have boards with different memberships dealing with problems that have substantial overlap, results in wasted energy and effort. Ideally, the by-laws should contain this provision to avoid potential problems. If the by-laws are silent, nominating committees can reduce the probability of differing memberships by putting forth a common slate of candidates for each board.

Most boards provide for staggered membership terms. Under this process, only a portion of the seats is up for re-election in any given year. This permits continuity among board members, which considerably eases the pressures on management and the other board members. In newer resorts, a common practice is to have three-year staggered terms with term limits of usually three terms.

Lastly, most timeshare boards do not compensate their directors. However, expenses related to attendance at board meetings are usually reimbursed. This makes service on the board as a Director truly a labour of love. The time commitment per year for most Directors includes two or three site visits, availability for conference calls, reading meeting and related materials and time to respond to other timeshare owners.

\section{SELECTION PROCESS OF BOARD NOMINEES}

As timeshare properties approach sell-out, the developer starts the transition to owner control. In this process, they identify eligible candidates and solicit nominations from the owners. The instrument used for the nomination is a nomination form containing the nominee's governance experience, familiarity with real estate/condominium/ timeshare issues and their willingness and ability to devote the requisite amount of time to the process and other information to assist with the selection. A vital indicator of the candidate's (future Director) interest in the timeshare property is whether they have occupied their units during their week of ownership. Owners who exchange out, rent or opt for promotional points are not on site and do not have the same perspective as those who occupy their units.

After the first owner board takes control of the timeshare property, subsequent nominations are regulated through a nominating committee consisting of the directors whose seats will not be up for election. The selection of board candidates is a very difficult process in which the resort manager can play an important role. The manager should work with the nominating committee in the selection of candidates. The manager can provide data as to how often the volunteer actually occupies his/her timeshare period as opposed to exchanging or renting. An effective board member is one who is on the property regularly and familiar with its operation. The manager can also inform the committee if there have been any issues with the candidate. 
One of the first issues facing the nominating committee is how many candidates to put forth. Most nominating committees believe that the owners should have some choice, so slates will typically contain more names than seats open. The ballot that is sent to the owners should contain biographical information for each candidate. It is very rare for there to be any active campaigning, so owners really do not have much evidence on which to base their vote. One of the critical concerns is to ascertain that enough owner weeks are voted to meet quorum requirements. Many resorts provide owner incentives for voting, such as a drawing for free exchange weeks among all those who voted. More progressive boards are exploring voting methodologies using the Internet, if permitted by state law. Depending on the size of the resort and the resources of the developer, votes will be tabulated either on site by management or by a representative of the developer. Results are usually reported at the annual meeting with the successful candidates taking their seats at the next board meeting.

Resort management can play a vital role in the orientation of new board members, as typically, most new board members know very little, if anything, about the operations and finances of the resort. In addition, new board members should be sent copies of the minutes of the board meetings for at least the prior two years of meetings, essential financial information (including audited financial statements) and copies of important timeshare documents (eg, master deed and by-laws).

Given that most resorts have owners from across the country, it is likely that directors will also be geographically dispersed. A good idea is to be sure that all board members have e-mail accessibility, which is a very efficient and cheap means of communicating with board members between meetings. E-mail is also useful to arrange dates for conference calls, to re-schedule meetings and other non-complex tasks.

\section{RESPONSIBILITIES OF THE BOARD OF DIRECTORS}

The board is responsible for the total operation and appearance of the timeshare resort and owners are most often a minority of the occupants. A variety of studies have shown that exchangers-in, renters and promotional guests comprise well over half of the occupants of most resorts in a given year. However, since it is the owners who pay the maintenance fees, reserves and taxes, boards primarily serve the owner's collective interests in governing a timeshare resort.

As is true for any Board of Directors, the board of a timeshare owners' association is responsible for the representation of the entire ownership of the association. In the performance of its responsibilities, the board executes a variety of functions, the most important of which are listed below and subsequently discussed in detail.

\section{PRIMARY RESPONSIBILITIES OF THE BOARD OF DIRECTORS}

- general oversight of resort operations

- selection, review and termination of the upper management of the resort 
- financial oversight of the resort

- review and approval of operations and capital expenditure budget

- review of resort working capital

- review of guest services and satisfaction levels

- review of timeshare re-sales.

\section{GENERAL OVERSIGHT OF RESORT OPERATIONS}

The resort itself is usually managed by professional outside staff, often under a contract with a management company. The management company implements operating policies that are usually established by the 'brand' so there is consistency between same-branded resorts. However, resort managers should implement these policies and procedures, keeping in mind the specifics of a particular timeshare location, ownership and user profile. The Board of Directors can be instrumental in ensuring the successful implementation of these brand standards. At the same time, if the management company plans to change operating procedures and standards that are brand mandated, they should work with the board to ensure owner approval.

\section{SELECTION, REVIEW AND TERMINATION OF THE UPPER MANAGEMENT}

When there is no contract with a management company, the board's role is clear: the responsibility is theirs. When there is a management contract with a management company, senior management usually reports to a representative of that company. Under these circumstances, it is imperative that the board insists on having input into the annual evaluation of senior management personnel and it should be consulted whenever a termination or hiring decision is being considered. ${ }^{8}$ The managers are employed by the management company and that company is responsible to the board and the association. Some documents now clearly state whose responsibility hiring, counselling and termination of managers is - usually in compliance with the relevant state employment laws.

\section{FINANCIAL OVERSIGHT OF THE RESORT}

In order to review the financial operations of the resort, the board should get periodic financial statements during the year which include:

- comparisons of actual to budget with variance explanations

- a forecast of year-end results

- receivables management report.

The annual financial statements should be audited, or minimally reviewed, by an independent certified public accounting firm. A representative of the accounting firm should meet with the board, or a committee to present and explain the audited results. Presently, this procedure is not a standard practice with most timeshare resort boards. 
However, with the trend to extend many of the provisions of the Sarbanes-Oxley Act to not-for-profits, it is expected that more timeshare associations will adopt this practice. Copies of the summarised financials should be sent to all members of the association. If state laws do not require this, due to the expense, this usually happens by request only. A common practice, especially in larger brand-related resorts, is to have the audited financial statements sent to the resort management who then is responsible for distributing them to all board members.

A major task of the board is to monitor the accounts receivable of the association. Strict policies must be established for dealing with members who are delinquent in their maintenance fee payments. Detailed accounts receivable aging schedules should be part of the regular board packet.

Finally, the board should make sure that adequate insurance is held for both the association's property and liability exposures. This can be a significant expenditure - especially in states subject to earthquake or hurricane damage.

\section{REVIEW AND APPROVAL OF OPERATIONS AND CAPITAL EXPENDITURE BUDGET}

The board is responsible for approving the annual operating budget and related reserve contributions. The board should approve the annual operating assessment per week for each owner in sufficient time to provide adequate notice to the owners. Management usually prepares a recommendation for the board to adopt prior to board meetings, to facilitate and expedite discussion at the board meeting.

Should the timeshare association have an operating surplus from the preceding year, the board needs to be sure that it is treating the surplus appropriately so as to minimise any potential federal income tax liability or violation of state law. Since there are options available to boards under the Internal Revenue Code for the tax treatment of unrelated business income (eg, investment income) earned by the association, the board would be prudent to seek professional assistance in making its decision.

A critical part of the maintenance fee decision is the approval of the reserve contribution per week. Reserves are the accumulations of funds to pay for capital improvements and refurbishment projects. A good reserve policy negates the need for special assessments (except in cases of uninsured catastrophes). There are several consulting firms who conduct 'reserve studies' to assist boards in determining the amount to collect for replacements and betterments. It is advisable for an outside firm every three years to update the reserve study, verifying useful lives and replacement costs and being sure that all assets are included. It would be imprudent for a board to assess reserves without having commissioned such a study periodically.

A sound fiscally managed timeshare association has a well-documented reserve policy and an appropriate policy for the investment of the reserve funds. Smaller developments can manage their own funds; larger ones frequently hire outside financial advisers who specialise in timeshare investments. Superior investment performance of the reserve fund results in lowering the amount of reserve contributions needed from the owners. 
This leads naturally into the next responsibility of the board, which is to review and approve of capital expenditures, which include refurbishments, replacements and betterments.

Typically, management will present recommendations to the board for their approval. A major decision, which occurs on a regular cycle, is the refurbishing of the interior of the timeshare units. This decision is most often the one involving the largest allocation of funds and therefore requires special attention. It is prudent for the board to instruct management to interview potential decorators and arrange for the preferred two or three firms to make a presentation at a board meeting.

The amount of the maintenance fee and reserve contribution requires a delicate balance. The total must be enough to fulfil all of the needs of the resort and hopefully, at the same time, keep the reserves in an actuarially sound position. However, a fee that is too high can hinder sales and resales. This is why during development, when it is not uncommon to have several representatives of the developer on the board, fees are usually set low. In fact, many management contracts provide for loss subsidies of operations during the first ' $x$ ' years - an incentive to keep the operating fee as low as possible.

The biggest danger is setting the reserve contributions too low in the early years of resort development. This inevitably will result is the resort having to play 'catch-up' with large increases in the reserve fees and frequently leads to a special assessment, particularly at the time of the first major refurbishment.

\section{REVIEW OF GUEST SERVICES AND SATISFACTION LEVELS}

The board is also responsible for monitoring guest satisfaction. They should periodically review the results of guest satisfaction surveys and analyse satisfaction scores by the type of user: owner, renter or exchanger. As satisfaction levels are partly a function of the types of facilities and amenities that the property provides, an ongoing dilemma of boards is how to respond to suggestions from their members for items that have limited appeal. While it is possible to provide a wide range of amenities and services, there is a cost associated with them. Therefore, the board must decide which services are appropriate, given that they are not operating a hotel. Many timeshare boards address this issue by identifying a list of core services that will be included in the operating fee, with an option of additional services on a "pay as you go' basis.

\section{REVIEW OF TIMESHARE RE-SALES}

The board should receive periodic reports on the status of re-sales within the development. During the sales phase, independent brokers typically handle these so data may not be as easy to accumulate. However, in larger resorts upon sell-out, the original developer usually provides re-sale activities and at this point data should be plentiful. It is in the best interests of the members of the association to have the re-sale values as high as possible and the time in inventory as low as possible. 
The board can also get involved in re-sales, if they have to foreclose on a week. At foreclosure, the association takes title to that week and has the responsibility for re-selling it. However, most associations are not equipped to be in the re-sale business. And, there is serious question as to whether they should be in that business since their 'core' business is operating the resort. As a result, recently Marriott Vacation Club International, for example, has begun a programme under which it purchases all of the foreclosed weeks from the association and then has the responsibility for marketing and selling them.

\section{OWNER-MANAGEMENT RELATIONS}

The board meeting is a very good opportunity for communication and dialogue between resort management and owners of the timeshare resort. The resort manager is the key management staff person on the resort's Board of Directors and works with the board president to prepare the meeting agenda. There will likely be several items on each meeting's agenda for which the resort manager will be responsible:

- a report on the status of action items from previous meetings

- a report on resort operations

- update on capital expenditures and reserve status

- periodic financial statements, including accounts receivable reports

- guest satisfaction updates.

In order to facilitate good discussion at the meeting, it is important to send the meeting agenda and associated documents ahead of time to the board members. In addition, the presence of the management executive team at the meeting is a positive signal to owners. The authors also recommend creating a positive ambiance at the meetings by paying close attention to other logistical and style details. These may include proper audiovisual arrangements, interactive meetings versus a one-way monologue, periodic self-assessment and follow-up communication document, such as meeting minutes.

\section{Management contract}

The relationship between the Board of Directors (representing the owners) and the management company (operating the resort) is contractual. The contract usually provides for automatic renewal, unless an affirmative action is taken by the board. Ordinarily, the contract will specify the amount of notice that must be given for a non-renewal.

The major factor causing a non-renewal is management's failure to perform up to the expectation of the board. Evidence of poor performance usually begins to reflect itself in poor guest satisfaction scores. It is not uncommon for board members to be contacted directly by owners or by resort employees concerned with the resort operations. Often, these problems can be corrected by working with the management company to either counsel or replace certain key on-site managers. 
Cancellation of the contract is a major move by the board that has farreaching implications. This is especially true in a resort developed and managed by an internationally known brand (eg, Hilton, Hyatt and Marriott). Most owners purchased their weeks based on their familiarity with and confidence in the brand. Should the board choose to divorce the resort from the brand by not renewing the management contract, the owners would lose several valuable perks (eg, participation in the brand's loyalty programme, central rentals and re-sales and exchange priorities). So, this decision is not an easy one and is one, should problems arise, that is best resolved by other means.

\section{EFFECT OF THE SARBANES-OXLEY ACT OF 2002}

Recent scandals involving Enron, WorldCom and several other major corporations have sent shockwaves throughout the corporate world. Corporations are now taking a close look at both their accounting and governance practices. One of the effects of this was the passage of The Sarbanes-Oxley Act, which was signed into law on 30 July 2002. This created new reporting requirements for public companies, mandated certain corporate governance reforms for public companies and created new auditor independence restrictions. How, if at all, does this affect, or even, should it affect the governance of timeshares?

The Act, of course, is not applicable to timeshare homeowners' boards, unless the development has been organised as a publicly held corporation. However, given the fact that many boards are responsible for large sums of accumulated cash funds and capital on behalf of the timeshare owners (equivalent to investors), we believe there are several provisions of the Sarbanes-Oxley Act that should be seriously considered and adopted by timeshare boards, where appropriate.

- The external auditor of the timeshare should rotate its lead or coordinating partner every five years.

- The board, if composed entirely of non-developer-related owners, should approve all non-audit services to be provided by the Home Owners Association (HOA) external auditor, greater than a predetermined amount. If there are developer-related owners on the board, a committee should be appointed composed entirely of nondeveloper-related owners to perform this function.

- HOA boards should seek to have at least one 'financial expert' on the board. This will require specific action by nominating committees. Generally, an owner who is a CPA (Certified Public Accountant) or one who has had extensive experience in the financial sector will meet this requirement.

In some instances, the external auditor contracts with the resort's management company. It is not uncommon, therefore, for an auditing firm to provide services to a large number of HOAs, all affiliated with the management company. As a result, the responsibility to implement some of the above recommendations will fall to the management company and the local HOA board will have to be sure their recommendations are put into place. 


\section{EUROPEAN PERSPECTIVE}

With the expansion of major brands into the European timeshare market, there is a significant difference in governance. Most European developments are sold on a 'right-to-use' basis as opposed to deeded ownership. As a result, owner participation in the resort governance is different. Most resorts, as a means of obtaining formal input from their owners, provide for boards of an advisory nature only. They have considerably less powers and duties as in deeded properties. Further, candidates for European timeshare resorts' advisory boards are usually selected by the management and the owners vote from management's slate. Quorum requirements for elections are generally non-existent; successful candidates are simply those receiving the greatest number of votes for any open positions.

\section{SUMMARY}

The physical appearance of timeshare resort properties is identical to traditional single owner/investor developments. However, an understanding of the timeshare ownership structure, with its diverse group of multiple owners and users, has important implications for the successful management of these properties. As active representatives of an otherwise passive ownership base, the Board of Directors is critical to the successful operation of the property. Therefore, management should have a good understanding of the role and responsibilities of the timeshare Board of Directors. While the day-to-day management of the property is in the hands of the management company, the board has an important role in setting policy, monitoring the activities and evaluating the resort's management.

\section{Acknowledgments}

The authors gratefully acknowledge the European perspective offered by Ms Becky Bagwell, Manager of Resort Operations Planning and Support Association Governance with Marriott Vacation Club International.

\section{References and Notes}

1. Suchman, D.R. (1999), 'Developing Timeshare and Vacation-Ownership Properties', Urban Land Institute, Washington, DC.

2. American Resort Development Association, http://www.arda.org/Content/NavigationMenu/ Industry Information.

3. American Resort Development Association (2002), 'The Timeshare Industry Resource Manual', ARDA, Washington, DC.

4. The Timeshare usable weeks calculation is based on 51 weeks as one week is closed for maintenance.

5. Woods, R. (2001), 'Important issues for a growing timeshare industry', Cornell Hotel and Restaurant Administration Quarterly, Vol. 42, No. 1, pp. 71-81.

6. The focus of this paper is on the nature of Governance in the US Timeshare industry. A limited reference is made in the endnotes to Timeshare governance practices in Europe. The paper is expected to be of value to non-US users as reference to compare their own practices.

7. The exact titles of the documents may vary from state to state and who writes them.

8. In the event of a termination, there may be circumstances that by law, and the privacy of the individual, cannot be shared with the board. 